\title{
LANGUAGE OF INSTRUCTION AND ITS EFFECT ON THE PERFORMANCE OF ACCOUNTING STUDENTS
}

\author{
M. Rossouw \\ School of Accountancy \\ Stellenbosch University \\ Stellenbosch, South Africa \\ e-mail: marelir@sun.ac.za
}

\section{ABSTRACT}

The purpose of this study was to investigate language of instruction and the effect it has on the performance of undergraduate Accounting students at a South African university. Students who have Afrikaans as their home language (Afrikaans students) are faced with the choice of receiving instruction in their home language or in English - the language of the business world. The research design was empirical in nature. Questionnaires were distributed to obtain students' school and university results, and to gather student and lecturer opinions on matters affecting language of instruction. The benefit that English might have in the workplace was ranked among lecturers as the most popular reason contributing towards Afrikaans students' choice for receiving instruction in English. It was found that, among Afrikaans students, home-language instruction leads to marginally better mid-year results at tertiary level. It was also interesting to discover that more than a third of student participants who are receiving instruction in Afrikaans indicated that they would consider a switch to English. This study proves that the choice of language of instruction in the undergraduate Accounting course would not necessarily be detrimental to student performance given that a student obtained an A or B symbol for their home-language subject in grade 12.

Keywords: home language, language of instruction, accounting

\section{INTRODUCTION}

The Chartered Accountant (South Africa) (CA (SA)) designation is a much sought-after qualification in South Africa. Only after completion of the appropriate university programme (both undergraduate and post-graduate), completing a learnership programme with a registered training office and passing two professional exams can a person register as a member with the South African Institute of Chartered Accountants (SAICA) and become a CA (SA). The aforementioned professional exams administered by SAICA (the Initial Test of Competence and Assessment of Professional Competence exams) are only available in Afrikaans or English (SAICA 2016a; SAICA 2016b). Accordingly, some South African universities offer its university programme in both Afrikaans and English. Afrikaans-speaking Accounting students are therefore in a unique position: they can choose to either study in Afrikaans (their home- 
language) or in English (the language most often used in the business world). Students who speak other languages do not have this choice between their home language and English.

Based on anecdotal reports from lecturers, students with Afrikaans as their home language (henceforth referred to as "Afrikaans students") often approach lecturers for advice on their language of instruction. Students perceive English as the preferred language of the business world, and rightly so, seeing that English is also considered the lingua franca of South Africa. Students are, however, hesitant to opt for instruction in English fearing that this might have a negative impact on their results (considering that English is not their home language). It is deemed worthwhile to investigate language of instruction and its effect on performance for Afrikaans students, as little empirical evidence is available regarding this matter. The results of such an investigation would aid lecturers in advising students regarding this matter.

\section{RESEARCH OBJECTIVE, RESEARCH QUESTIONS AND THE CONTRIBUTION OF THIS STUDY}

The purpose of this study is to investigate language of instruction and its effect on performance for Afrikaans Accounting students. Research questions were designed in order to meet the stated objective. Four research questions were identified for this purpose:

i. Why do Afrikaans students choose English as language of instruction?

ii. What is the effect of language of instruction on university studies?

iii. How does the performance of Afrikaans students receiving instruction in their home language compare to those receiving instruction in English?

iv. Would students switch to an alternative language of instruction?

Even though the results of this study cannot be generalised to other fields of study, the results may be of interest to other environments where language of instruction differs from home language. The results of the investigation would assist lecturers and university staff in the admissions office in advising students regarding the effect of their choice of language of instruction on performance.

\section{LITERATURE REVIEW}

While all students have to adapt to a more intensive learning environment at tertiary institutions, the effect of receiving instruction in a second language may cause added difficulty. Teemant (2010, 94-96) conducted a study on students who receive instruction in English, but with a 
different home language than English, and found them to struggle with subject-specific terminology, to feel "lost in a flood of terminology", and to struggle to keep pace with classes. This literature review focuses on factors that could influence the choice of an Afrikaans Accounting student to receive instruction in either Afrikaans or English, as well as the effect of language on performance.

\section{Factors influencing the choice of language of instruction}

Literature shows that a student's perceptions of several matters affect their decision about language of instruction. These include the student's perceptions regarding his/her language proficiency in a specific language as well as the benefit of English in the workplace.

\section{Perceived language proficiency of student}

Afrikaans-speaking students might have taken English Home Language as a subject at school, and perceive themselves to be proficient in English as a result. There are, however, indication that high school marks in English Home Language might be misleading and lead to a false sense of confidence. Du Plessis $(2014,1)$ found that the English Home Language NSC examination, from 2008 to 2012, cannot be considered indicative of advanced literacy ability, but rather "basic and general proficiency". If the English Home Language subject is not at an advanced level, it could explain Farmer and Anthonissen's $(2010,12)$ finding of increased enrolments for grade 10 and 11 scholars in the English Home Language class in the Helderberg area. If Afrikaans students perform well in this subject at school, they may believe that their schoolleaving mark reflects their true ability in English and therefore choose to study in English. Such students may then experience difficulty at tertiary level.

Studies show differing views between students and lecturers about language competency. This is especially true for students attending class in their second language (Miller 2007, 759; Otaala and Plattner 2013, 128). English second-language students who received instruction in English rated their own competency in English much higher than lecturers did (Otaala and Plattner 2013, 128).

\section{Perceived benefit of English as language of instruction}

In a study conducted by De Wet $(2002,121)$ at the University of the Free State (UFS), the majority of student respondents attested to the importance of home-language instruction for effective learning. However, Bornman, Potgieter and Pauw (2013, 370) found (in their study on the language choices of Afrikaans-speaking students at the University of South Africa) that 
only 53 per cent of Afrikaans students study in Afrikaans (compared to 47\% who study in English). In fact, even after equal status was granted for all 11 official languages in the South African Constitution post 1994, the majority of learners still prefer English as language of instruction (De Wet and Wolhuter 2009, 359).

English is commonly acknowledged as the lingua franca in many walks of life in South Africa (Bornman et al. 2013, 365; Farmer and Anthonissen 2010, 11; Oostendorp and Anthonissen 2014, 70; De Wet and Wolhuter 2009, 359). On its own, this explains why so many Afrikaans students choose English as their language of instruction. Afrikaans/English bilingual students surveyed at SU admitted to the usefulness of English for social and academic purposes, while students at UFS viewed English as the most important language in politics, education, science and technology, as well as trade and industry (De Wet 2002, 121; Oostendorp and Anthonissen 2014, 80). Heunis (2016, 11), however, stresses that instruction in one's home language does not exclude one from participation in international discussions.

Bornman et al. (2013, 373) tested student responses to identify the most important determining factor in choosing to study in English. The factor with the highest average response by far was that textbooks are predominantly in English. Other important reasons included English's stance as world language, access to English terminology and English as the preferred language in the workplace. Janse van Rensburg, Coetzee and Schmulian $(2014,10)$ suggest that the reading comprehension of second language students may be better if they receive instruction in the same language as the document read. The majority of prescribed textbooks in Accounting courses are only available in English. Afrikaans students who choose to receive instruction in English might therefore generate meaning from text better, and maybe more quickly, than an Afrikaans student receiving instruction in their home language.

\section{Effect of language on performance}

Several studies have been conducted on the influence of language on student performance. Varying opinions on this matter have been published, especially related to students studying towards a degree in commerce (Baard, Steenkamp, Frick and Kidd 2010, 140; Drennan and Rohde 2002, 27; Steenkamp 2014, 291; Wong and Chia 1996, 187). Fraser and Killen (2003, 259) investigated the opinions of students and lecturers in the Bachelor of Arts faculty, with specific focus on academic success in the Education degree at the University of Pretoria. They found a high level of agreement between students and lecturers regarding success factors, but disagreement about factors that might lead to failure, language aspects included. 


\section{Effect of language proficiency on performance}

Oostendorp and Anthonissen's $(2014,75)$ study at SU on language choices of bilingual students found that students who chose to receive instruction in English did not believe this choice had a negative impact on their academic performance. They did, however, acknowledge that a fair level of proficiency in English is needed in order to do well at university, especially since textbooks are predominantly in English (Oostendorp and Anthonissen 2014, 78). In a study conducted with post-graduate Accounting students at SU, it was found that advanced literacy skills (deduced from respondents' grade 12 results in their home language subject) lead to better results in the CTA programme (Steenkamp 2014, 291). Wong and Chia (1996, 187) also found a correlation between proficiency in English and performance in Financial Accounting at firstyear level. Eiselen and Geyser (2003, 122) did an inverse study. In their study, they distinguished between "achieving” and "at risk" Accounting students (based on their marks for Accounting at first-year tertiary level) and tested their language proficiency. The results showed the "at risk" students having a significantly poorer vocabulary compared to "achieving" students. The “poor literacy skills of students” as reason for lack of performance was rated much higher by lecturers than students in the Fraser and Killen study $(2003,258)$ showing that students and lecturer perceptions on the matter are often contrasting.

\section{Effect of language of instruction on performance}

Drennan and Rohde (2002, 34) did a study on introductory level Management Accounting students who receive instruction in English and found no correlation between students' performance and whether they have English as their first or second language. They did, however, found that students with English as first language outperform others in advanced levels of the same subject.

In Fraser and Killen $(2003,258)$ "poor language ability of lecturers” was rated as the $32^{\text {nd }}$ biggest factor (out of 55) contributing towards failure by lecturers, whereas students (both firstyear and senior students) rated this as ninth overall. Students may well perceive lecturers' teaching ability as a factor contributing towards their academic success (Steenkamp, Baard, and Frick 2009, 127). Ogier (2005, 477) evaluated student ratings for lecturers for whom English was a second language in the Commerce Faculty at the University of Canterbury. They found that these lecturers received lower ratings from students compared to lecturers with English as their home language.

The fact that textbooks are available in one language only is rated more highly by students than lecturers (as factor leading to failure) (Fraser and Killen 2003, 258). Students' feedback 
regarding textbooks' availability in one language only, and this being a factor which is believed to contribute towards failure, also underlines why Bornman et al. $(2013,373)$ found this to be a reason why Afrikaans students opt for instruction in English.

\section{RESEARCH METHODOLOGY}

\section{Research design}

The research design is empirical in nature. The research questions are answered by generating primary data using questionnaires (that were developed based on an extensive literature review). The data generated is then analysed to quantify statistically significant associations between data items or identify trends from research results.

\section{Sample selection}

Stellenbosch University (SU) is one of SAICA's accredited universities to offer an Accounting programme. The choice for language of instruction in the Accounting programme at SU is Afrikaans or English, in line with the languages in which the professional exams are set by SAICA. Students have the choice to register for this course in either one of these languages at the beginning of each academic year. SU was identified, with two focus groups, as sample to be used in this study.

The first focus group was undergraduate Accounting students (first year to third year) who are studying towards becoming a CA (SA) and who chose Afrikaans as their home language at registration in 2016. Data collected from students will be used to compare the performance of students who study in their home language and those who study in English in order to answer research question three. The second focus group was the lecturers of these students. Student and lecturer opinions on language matters will be used to answer the remaining research questions. It was decided to send out two questionnaires to gather the necessary data.

\section{Questionnaires' design}

Two questionnaires were designed to test the perceptions of students and lecturers, similar to the study by Fraser and Killen (2003), on the effect of language of instruction. The student questionnaire consisted of five sections. Section one focused on biographical information. Section two collected data on respondents' school experience: their language of instruction, their chosen subjects and symbols obtained on their grade 12 or NSC certificate. Section three focused on university experience and respondents' choice of language of instruction at tertiary level. Section four asked respondents to evaluate statements on how language affects 
performance in the Accounting programme. These statements were put to students in Likertscale format. The last section was only available for respondents who have been in the Accounting programme for more than one year. This section aimed to determine how many students have switched from one language of instruction to another.

The lecturers' questionnaire did not include biographical information but focused on language preferences and lecturing experience. The questionnaire consisted of three sections. Section one collected data on lecturer profiles and language preferences. Section two mirrored section four of the questionnaire for students. Statements on how language affects performance in the Accounting programme were put to lecturers in Likert-scale format. The last section focused on perceptions regarding student choices relating to language of instruction. The opinions of lecturers about why Afrikaans students choose to study in English were based on results by Bornman et al. (2013, 374).

Likert-scale questions, used in section four of the student questionnaire and section two of the lecturer questionnaire, were categorised in five major groupings, namely strongly disagree, disagree, neutral, agree and strongly agree. These groupings were used to compare student and lecturer opinions on the same question. Students were given the option of not answering Likert-scale questions.

\section{Measuring student performance}

Student performance for the undergraduate Accounting degree at SU is measured quantitatively. Marks obtained in tests and examinations determine success. This study used the most recent results available at the time of conducting the study, namely the progress mark (mid-year mark in 2016) in students' current year of study. Students' progress mark for Financial Accounting at SU, their choice of language of instruction at SU and the results obtained for their home language subject in grade 12 were used to determine if language of instruction causes a difference in students' performance in the Accounting course.

\section{Data collection}

The student questionnaire was distributed to undergraduate Accounting students at SU who selected Afrikaans as their home language at registration in 2016. The student questionnaire was sent to 779 Afrikaans undergraduate Accounting students and was available for ten days. The lecturer questionnaire was distributed to employees lecturing in the School of Accountancy at SU at the time of the study. The lecturer questionnaire was sent to 66 lecturers and was available for two weeks. Both questionnaires were distributed via an email containing a 
hyperlink to the online questionnaire. All respondents participated voluntarily and their feedback remained anonymous. The relevant university authorities provided ethical clearance and institutional permission for the study.

\section{Statistical analysis}

Responses were evaluated using the Statistica software program. Descriptive statistics were used to analyse respondent profiles. Correlation and ANOVA studies were done (F-tests for nominal data) to analyse different opinions between student and lecturer respondents. Statistical significance was tested by applying a 5 per cent significance level $(\mathrm{p}=0.05)$. Likert-scale statements were analysed by attaching a value to each response option where 1 = "strongly disagree” and 5 = "strongly agree”.

\section{RESEARCH FINDINGS}

The student questionnaire was completed by 295 respondents (38\% of the population). One respondent was disqualified from the study when he/she chose English as home language. Two other respondents were disqualified based on the fact that they only had provisional acceptance into the accredited Accounting programme at SU, and were registered for an introductory Financial Accounting module in their first year of study (with a much lower level of difficulty than the normal module). Thus, the results of 292 students were analysed. A total of 90 per cent of students were between the ages of 18 and 21 (the expected age for undergraduate Accounting students), while 10 per cent were older. There were 138 students in their first year of the Accounting course (47\%), 66 in their second (23\%), and 88 in their third (30\%).

The lecturer questionnaire was completed by 46 lecturers (70\% of the population). Most of the participating lecturers (87\%) chose Afrikaans as their home language. When asked about their preferred language of instruction, 46 per cent preferred Afrikaans and 17 per cent preferred English. Thirty-seven per cent felt equally comfortable lecturing in both languages. The majority of respondents (56\%) have been lecturing at SU for more than four years. Only 20 per cent had less than two years' lecturing experience.

\section{Research question (i): Why do Afrikaans students choose English as language of instruction?}

Lecturers were asked to rank the top three (out of six) factors that influence Afrikaans students' choice to study in English (Table 1). The factors listed in the questionnaire were based on the findings of Bornman et al. (2013, 374). Lecturers ranked the advantage that English has in the workplace as the most popular reason. It is also statistically more significant than any other 
reason listed in the questionnaire, with $\mathrm{p}=<0.01$ against all other reasons. The fact that legislation and textbooks are in English was ranked second, being schooled in English third, and increased chances of finding work abroad fourth. Lecturers ranked advice from parents, a mentor or other students as the fifth reason and the least popular reason was the fear that Afrikaans might soon not be an option for language of instruction at SU. The difference between rankings two to six was not significant. The opinions of SU lecturer respondents in this study support the findings of the University of South Africa (UNISA) student survey on the same question (Bornman et al. 2013, 373). Another ad-hoc reason provided by lecturers on the same question included the view that students are advised to study in English by the training office at which the student have committed to work after their studies.

Table 1: Lecturer perceptions on reasons why Afrikaans students choose English as language of instruction

\begin{tabular}{|l|c|c|}
\hline Reasons for choosing English as language of instruction & Ranked & $\begin{array}{c}\text { Mean } \\
\text { (Standard deviation) }\end{array}$ \\
\hline Advantage in the workplace & 1 & $2.00(1.03)$ \\
\hline Legislation and textbooks are in English & 2 & $2.70(1.07)$ \\
\hline Attended school in English & 3 & $3.02(1.20)$ \\
\hline $\begin{array}{l}\text { English is spoken in most countries. Therefore, being educated in } \\
\text { English will increase chances of finding work abroad }\end{array}$ & 4 & $3.04(1.05)$ \\
\hline Advice from parents/mentor/other students & 5 & $3.46(1.05)$ \\
\hline $\begin{array}{l}\text { Fear that Afrikaans might soon not be an option for language of } \\
\text { instruction at Stellenbosch University }\end{array}$ & 6 & $3.70(0.70)$ \\
\hline
\end{tabular}

The majority of lecturers surveyed are CA (SA)'s. Lecturers were asked to indicate in which language they predominantly worked, after completing their studies and before being employed at SU. Half of Afrikaans lecturers (50\%) worked mainly in an English environment post studies. This was followed by 45 per cent of lecturers indicating a predominant Afrikaans environment and 5 per cent found their working environment post studies to be equally Afrikaans and English. It can therefore be deduced that Afrikaans students who choose English as their language of instruction, based on the belief that they will benefit from this choice once they enter the workplace, might rightly end up to work in a predominantly English environment where they could gain the advantage that they envisioned.

The perceived advantage that instruction in English has for Afrikaans students in the workplace was also included in both the student and lecturer questionnaires in a Likert-scale statement as follows: "Receiving instruction in English will benefit Accounting students once they enter the workplace”. The majority of student and lecturer respondents agreed with this statement, with students agreeing a bit more fervently. 


\section{Research question (ii): What is the effect of language of instruction on university studies?}

An F-test was done (for ordinal data) on the same Likert-scale questions put to student and lecturer respondents to test whether their opinions differed significantly regarding language matters (Table 2).

Table 2: Comparisons between student and lecturer opinions

\begin{tabular}{|c|c|c|c|c|c|c|}
\hline \multirow[b]{2}{*}{ Likert-scale question } & \multicolumn{2}{|c|}{ Students } & \multicolumn{2}{|c|}{ Lecturers } & \multirow[b]{2}{*}{$\mathbf{F}$} & \multirow[b]{2}{*}{$\underset{p-\text { value }}{F}$} \\
\hline & Average & $\begin{array}{l}\text { Standard } \\
\text { deviation }\end{array}$ & Average & $\begin{array}{l}\text { Standard } \\
\text { deviation }\end{array}$ & & \\
\hline $\begin{array}{l}\text { Receiving instruction in their home } \\
\text { language will lead to better results for } \\
\text { Afrikaans students. }\end{array}$ & 4.15 & 1.00 & 4.33 & 0.87 & 1.19 & 0.28 \\
\hline $\begin{array}{l}\text { If the lecturer is not lecturing in his/her } \\
\text { home language, this will definitely have } \\
\text { a negative impact on student results. }\end{array}$ & 3.24 & 1.13 & 2.59 & 1.02 & 13.72 & $<0.01$ \\
\hline $\begin{array}{l}\text { The quality of Afrikaans and English } \\
\text { lectures in the Accounting programme } \\
\text { at SU are the same. }\end{array}$ & 3.61 & 0.91 & 3.67 & 1.01 & 0.18 & 0.67 \\
\hline
\end{tabular}

There is a statistically significant difference in opinion regarding the negative impact on student results when lecturers are not lecturing in their home language. Student respondents are more likely to agree with this statement and lecturer respondents more likely to disagree $(p<0.01)$. The difference in opinion regarding a factor which might lead to student failure coincides with Fraser and Killen (2003, 258) who also found a difference in opinion regarding language abilities of lecturers and the possibility of this fact contributing towards failure.

The difference in opinion on the other questions were not considered to be significant. Both groups were inclined to agree that the quality of Afrikaans and English lectures in the Accounting programme at SU are the same. The student respondents' opinion regarding the quality of lectures and lecturers not lecturing in their home language is quite contradicting. They seem to agree that the quality of Afrikaans and English lectures are the same, but they also agree with the statement that lecturers who are not lecturing in their home language have a negative impact on their results. It is interesting to note that student and lecturer respondents lean towards "strongly agreeing" that instruction in their home language will lead to better results for Afrikaans students.

\section{Research question (iii): How does the performance of Afrikaans students receiving instruction in their home language compare to those receiving instruction in English?}

Of the student respondents, 27 per cent indicated that their language of instruction at SU is English. When the average progress marks of respondents who receive instruction in Afrikaans 
and those who receive instruction in English are compared, it seems that respondents who receive instruction in their home language are performing better. However, the difference is not statistically significant ( $p=0.30$ ) (Table 3). This difference was further disaggregated per year of undergraduate study (first-, second- or third-year students). It was confirmed that the difference in average progress mark is not statistically significant in any year of study (interaction $p=0.78$ ). When asked how they believe their performance compared with the class average, the majority of both groups indicated a belief that they are performing better, or on par, with the class average. It appears as though most Afrikaans students, irrespective of their language of instruction, feel content with their marks in relation to the class average.

Table 3: Average progress mark for Afrikaans students receiving instruction in Afrikaans versus English

\begin{tabular}{|l|c|c|c|c|c|}
\hline \multirow{2}{*}{$\begin{array}{c}\text { Undergraduate year } \\
\text { of study }\end{array}$} & \multicolumn{2}{|c|}{$\begin{array}{c}\text { Language of instruction is } \\
\text { Afrikaans }\end{array}$} & \multicolumn{2}{c|}{$\begin{array}{c}\text { Language of instruction is } \\
\text { English }\end{array}$} & \multirow{2}{*}{ p-value } \\
\cline { 2 - 5 } & $\#$ & Average PM (\%) & $\#$ & Average PM (\%) & \\
\hline First year & 97 & 60.46 & 41 & 57.20 & 0.16 \\
\hline Second year & 44 & 60.95 & 22 & 60.32 & 0.84 \\
\hline Third year & 71 & 56.61 & 17 & 54.29 & 0.65 \\
\hline Total & $\mathbf{2 1 2}$ & & $\mathbf{8 0}$ & & 0.30 \\
\hline
\end{tabular}

\section{The relationship between language of instruction, language proficiency and performance}

Even though there was no significant difference in performance between Afrikaans students who study in Afrikaans versus those who study in English, further investigation was made to evaluate if students with a lower language proficiency perform worse if they choose to receive instruction in English. A comparison was drawn between the symbol respondents obtained for their home-language subject in grade 12 (A, B, C or D) and their progress mark at university (Table 4). It was notable that respondents who obtained an A for their home-language subject at school had a better average progress mark than respondents with a B or C. This finding supports the results of Steenkamp (2014, 291) and Eiselen and Geyser (2003, 122), and underlines the importance of strong language skills in Accounting studies. The difference in performance, however, between students who are receiving instruction in Afrikaans versus English, and who obtained an A or B symbol for their home-language subject in grade 12, is not statistically significant. Students who obtained a C, D or who was unsure of their homelanguage subject symbol represented only 5 per cent of the respondents. Their results were not analysed. 
Table 4: Average progress mark per symbol obtained for grade 12 home-language subject

\begin{tabular}{|l|c|c|c|c|c|}
\hline \multirow{2}{*}{$\begin{array}{l}\text { Symbol obtained for } \\
\text { home-language subject } \\
\text { in grade 12 NSC exam }\end{array}$} & \multicolumn{2}{|c|}{$\begin{array}{c}\text { Language of instruction is } \\
\text { Afrikaans }\end{array}$} & \multicolumn{2}{c|}{$\begin{array}{c}\text { Language of instruction is } \\
\text { English }\end{array}$} & \multirow{2}{*}{ p-value } \\
\cline { 2 - 6 } & $\#$ & Average PM (\%) & $\#$ & Average PM (\%) & \\
\hline A $(80 \%+)$ & 130 & 60.86 & 40 & 60.40 & 1.00 \\
\hline B $(70 \%+)$ & 73 & 56.51 & 33 & 54.61 & 0.47 \\
\hline
\end{tabular}

The results confirm that language proficiency (based on grade 12 home-language subject results) enhance performance: students with a higher language proficiency obtained a better progress mark than students with a lower language proficiency. The level of proficiency (whether a student obtained an A or B symbol) does not seem to make a significant difference in performance at tertiary level whether an Afrikaans student receive instruction in Afrikaans or English. The performance of an Afrikaans student with a lower language proficiency (B symbol for home-language subject in grade 12) is not significantly lower if they choose English as language of instruction.

\section{Research question (iv): Would students switch to an alternative language of instruction?}

Lastly, it was investigated whether students would consider switching from their current choice of language of instruction. 38 per cent of students who receive instruction in Afrikaans indicated they would consider a switch to English. This is much higher than the results of Bornman et al. (2013, 373) where only 4.5 per cent of Afrikaans students at UNISA indicated that they are planning a switch to instruction in English. Only 9 per cent of students who receive instruction in English indicated they would consider a switch to Afrikaans. Interestingly enough, when student respondents (who are not in their first year) were asked whether their language of instruction is the same in 2016 as in 2015, 97 per cent agreed. Only 3 per cent have changed their language of instruction from 2015 to 2016.

\section{CONCLUSION}

The objective of this study was to investigate language of instruction and its effect on performance for Afrikaans Accounting students. The study was prompted by anecdotal reports from Accounting lecturers who are experiencing an increased number of Afrikaans students seeking advice on their language of instruction. Questionnaires were designed to answer four research questions and distributed to students and lecturers. A response rate of 38 per cent and 70 per cent were achieved respectively for the student and lecturer questionnaires.

Research question one aimed to find out why Afrikaans students choose English as language of instruction. The question was answered when lecturer respondents ranked the 
benefit that English might have in the workplace as the most popular reason contributing towards Afrikaans students' choice for receiving instruction in English. This reason was statistically more significant than all other reasons listed. Considering that 50 per cent of Afrikaans lecturers worked in a predominantly English environment, it is justified to think that instruction in English might be beneficial for Afrikaans students post studies. Student respondents supported this ranking when the majority attested to the benefit of English instruction post studies.

Statements were made, in both questionnaires, regarding language of instruction. These statements were made in Likert-scale format, in order to determine the perceived effect of language of instruction on university studies as per research question two. The only statement with a statistically significant difference in opinion between the two groups of respondents, was regarding the language in which lecturers delivered lectures. The majority of lecturers do not believe that student results are negatively impacted if they are not lecturing in their home language, while students are inclined to believe that it does have a negative impact. Student respondents contradicted this response when they agreed that the quality of Afrikaans and English lectures at SU are the same. Lecturers also agreed that the quality of lectures at SU are the same. It was interesting to note that both groups agreed quite convincingly that instruction in their home language will lead to better results for Afrikaans students.

Afrikaans students who receive instruction in English were compared to their counterparts, who receive instruction in their home language, to determine how their performance compare in research question three. Even though 27 per cent of student respondents receive instruction in English, the majority of student and lecturer respondents indicated a belief that home-language instruction will lead to better results. In this study, students who receive home-language instruction performed marginally better. However, the difference in performance was not statistically significant. The relationship between language of instruction, language proficiency and performance were also investigated. Strong literary skills (based on home-language subject marks in grade 12) do seem to benefit undergraduate Accounting students. It was evident from the data that students with a higher symbol for their grade 12 home-language subject obtained a higher average progress mark at SU. The difference in progress mark, however, between students receiving instruction in Afrikaans and English, for students with the same level of language proficiency, was not statistically significant. This leads to the conclusion that there might not be a significant difference in performance for an Afrikaans student who receives instruction in Afrikaans or English, given that they had an A or B symbol for their home-language subject in grade 12. And lastly, to answer research question 
four, it was investigated whether students would consider a switch to an alternative language of instruction. More than a third of students who are receiving instruction in Afrikaans indicated they would consider a switch to English.

Most students choose their language of instruction at the age of 18, before commencing with an undergraduate Accounting degree. This study proves that the choice of language of instruction in the undergraduate Accounting course at SU would not necessarily be detrimental to student performance given that a student obtained an A or B symbol for their home-language subject in grade 12 .

Future research is recommended to evaluate the impact of instruction language on the undergraduate Accounting programme pass rate, and consequential acceptance (or not) into the CTA programme. Lastly, it might be insightful to survey CA (SA)'s with Afrikaans as home language and their experience of English in the workplace.

\section{REFERENCES}

Baard, R. S., L. P. Steenkamp, B. L. Frick and M. Kidd. 2010. Factors influencing success in first-year Accounting at a South African university: The profile of a successful first-year Accounting student. SA Journal of Accounting Research 24(1): 129-147.

Bornman, E., P. H. Potgieter and J. C. Pauw. 2013. Taalkeuses en -opinies van Afrikaanssprekende studente aan Unisa. Tydskrif Vir Geesteswetenskappe 53(3): 361-376.

De Wet, C. 2002. Factors influencing the choice of English as language of learning and teaching (LoLT) - A South African perspective. South African Journal of Education 22(2): 119-124.

De Wet, C. and C. Wolhuter. 2009. A transitiological study of some South African educational issues. South African Journal of Education 29(3): 359-376.

Drennan, L. G. and F. H. Rohde. 2002. Determinants of performance in advanced undergraduate management accounting: An empirical investigation. Accounting and Finance 42(1): 27-40.

Du Plessis, C. 2014. Issues of validity and generalisability in the Grade 12 English Home Language Examination. Per Linguam: A Journal of Language Learning 30(2): 1-19.

Eiselen, R. and H. Geyser. 2003. Factors distinguishing between achievers and at risk students: A qualitative and quantitative synthesis. South African Journal of Higher Education 17(2): 118-130.

Farmer, J. and C. Anthonissen. 2010. Transitions and translations from Afrikaans to English in schools of the Helderberg area. Stellenbosch Papers in Linguistics 39: 1-23.

Fraser, W. J. and R. Killen. 2003. Factors influencing academic success or failure of first-year and senior university students: Do education students and lecturers perceive things differently? South African Journal of Education 23(4): 254-263.

Heunis, J. 2016. Wraak op 'n taal werk nie. Rapport Weekliks 18 September: 11.

Janse van Rensburg, C., S. A. Coetzee and A. Schmulian. 2014. South African financial reporting students' reading comprehension of the IASB Conceptual Framework. Journal of Accounting Education 32: 1-15.

Miller, L. 2007. Issues in lecturing in a second language: Lecturer's behaviour and students' perceptions. Studies in Higher Education 32(6): 747-760.

Ogier, J. 2005. Evaluating the effect of a lecturer's language background on a student rating of teaching form. Assessment \& Evaluation in Higher Education 30(5): 477-488. 
Oostendorp, M. and C. Anthonissen. 2014. Multiple voices in bilingual higher education: Language choices of Afrikaans/English bilinguals at Stellenbosch University. Per Linguam: A Journal of Language Learning 30(2): 69-87.

Otaala, L. A. and I. E. Plattner. 2013. Implicit beliefs about English language competencies in the context of teaching and learning in higher education: A comparison of university students and lecturers in Namibia. International Journal of Higher Education 2(3): 123-131.

SAICA. 2016a. Qualifying examination regulations for the initial test of competence (ITC). https://www.saica.co.za/Portals/0/LearnersStudents/Examinations/Candidate\%20guide\%20to\%2 0the\%20ITC\%202015.pdf (Accessed 16 September 2016).

SAICA. 2016b. Assessment of professional competence (APC) regulations. https://www.saica.co.za/Portals/0/LearnersStudents/Examinations/Part_II_APC_Exam_regulatio ns.pdf (Accessed 16 September 2016).

Steenkamp, G. 2014. How pre-admission characteristics affect the performance of CTA students at a South African university. Journal of Economic and Financial Sciences 7(2): 283-298.

Steenkamp, L. P., R. S. Baard and B. L. Frick. 2009. Factors influencing success in first-year accounting at a South African university: A comparison between lecturers' assumptions and students' perceptions. South African Journal of Accounting Research 23(1): 113-140.

Teemant, A. 2010. ESL student perspectives on university classroom testing practices. Journal of the Scholarship of Teaching \& Learning 10(3): 89-105.

Wong, D. S. N. and Y. Chia. 1996. English language, mathematics and first-year financial accounting performance: A research note. Accounting Education 5(2): 183-189. 